Ann. Génét. Sél. anim., I973, 5 (2), 239-256.

\title{
COST-EFFECTIVENESS AND POPULATION STRUCTURE IN CATTLE BREEDING PROGRAMMES (1)
}

\author{
E. P. CUNNINGHAM \\ The Agricultural Institute, \\ Department of Animal Breeding et Genetics, \\ Dunsinea, Castleknock, Co. Dublin, \\ Ireland
}

\section{SUMMARY}

Cost-effectiveness requires that a breeding programme be both genetically and economically well-planned. Planning consists of deciding between alternative courses of action. These decisions arise at both the strategic and tactical level. The point is made that the tactical choices have been well served by science, but that the more important strategic ones have not been.

A formal framework is described in which the sequence of decision-making required for an animal breeding programme is treated systematically. Current work in the genetic/economic planning of cattle breeding schemes is reviewed. The interaction of breeding programmes and population structure is dealt with in some detail.

\section{INTRODUCTION}

The contribution which the science of animal genetics makes to the practice of animal breeding is to provide a basis for rational decision-making. That is to say that from a reasonably well-established knowledge of how inheritance works (both in individuals and in populations), we can select between individuals, strains and mating systems and predict with reasonable accuracy the genetic consequences of our decisions. If the economic cost of the alternative courses of action can be measured, and if their results can also be expressed in monetary terms, it becomes possible to calculate the cost-effectiveness of a breeding programme. This is to state

(1) Invited report presented in the Study Meeting of the European Association for Animal Production, joint Session of Commission on Cattle Production and Commissionon Animal Genetics, Verona, Italy october 6 th, I972. 
in very broad and simple terms, what can be an extremely complex situation. The following factors may all interact to produce this complexity :

- multiplicity of breeding goals,

- presence of both additive and non-additive genetic variation,

- variation in production systems,

- structure of the animal population concerned,

- structure of the human organization concerned.

However, the basis of any breeding programme remains the physical fact of Mendelian inheritance, and we can perhaps order this commplexity best by letting the biology lead the way.

\section{THE GENERAL STRATEGY. OF LIVESTOCK IMPROVEMENT}

There is a natural sequence of decisions which must be made in the logical development of any livestock improvement programme. I have attempted to describe them schematically in figure $I$.

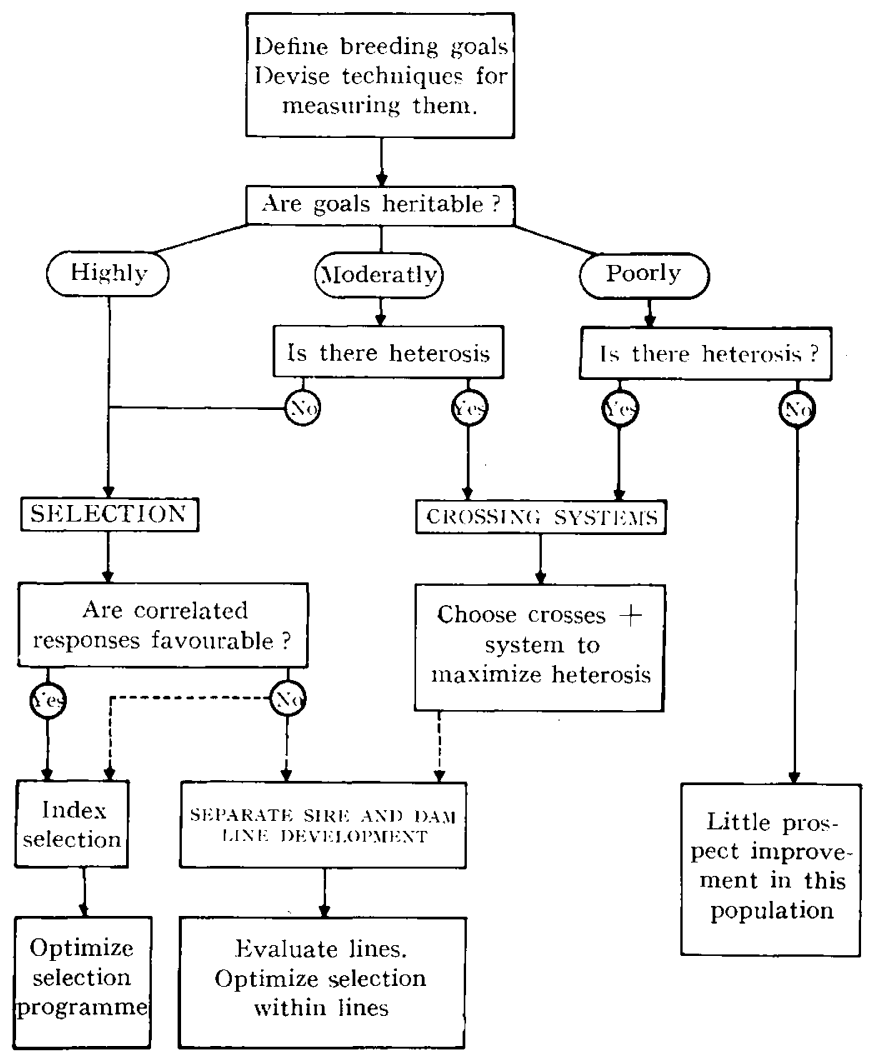

FIG. I. - General strategy of livestock improrement

Stratégie générale de l'amélioration du bétail 
In the first place, we need an agreed choice of breeding goals. The practice has too frequently been to aim for an ill-defined mixture of aesthetic and economic merit. In fact it is probably fair to say that most of the dialogue between breeders in the traditional sense and scientists involved in breeding has never progressed beyond this initial question.

Given that agreed objectives are possible, the next problem is that of measuring them. This poses no difficulty for some traits like backfat thickness or litter size, but can be a real obstacle for others, such as conformation, meat quality or disease resistance. The obstacle may not be solely the technical difficulty of measurement, but, as in the case of carcass composition in cattle, the cost. Associated with this complex of defining and measuring the selection goals is the question of placing economic values on them.

With agreed and measurable goals it is reasonable to ask next wheter genetic improvement is possible. We look first for additive genetic variation so that we can estimate the probable response to selection.

More scientist man years have been devoted to heritability estimation than to any other aspect of animal genetics. This was necessary in the same sense as mapmaking is necessary. For the future, periodic revision of the genetic parameters studied should be an almost automatic part of any well-designed breeding scheme. If the goals are sufficiently heritable, selection will be effect. If heritability is low, selection will not be effective. However, in this situation, evolution has frequently provided enough non-additive variation to make the exploitation of heterosis worthwhile. With complex goals, it may even be necessary to pursue both selection and heterosis responses. In general, the traits of major economic importance in cattle are sufficiently heritable to call for the selection alternatives. This is fortunate, because selection responses are cumulative, in contrast to those from heterosis, and in addition do not incur the extra costs which are sometimes required to support a population structure designed for crossing.

If the genetic architecture of the population indicates that neither additive nor heterotic responses can be expected, then either a change of breeding goals or a change of population is needed before genetic improvement is possible. If usable heterosis is present, then one is faced with the choice of crossing system and its components to maximize the heterotic effect. This involves the testing of strains (perhaps natural strains, such as breeds of cattle, or artificial lines as are used in poultry), and of mating systems. This could conceivably be the end point of a breeding programme, with perhaps nothing further to do but continue strain testing and replacement where indicated. However, the more usual situation is that heterotic effects are important only for part of breeding goal, and that the exploitation of heterosis for some traits is accompanied by continued selection within strains for other traits.

The construction of a selection programme to exploit additive variation is now supported by a great deal of theoretical and experimental work. The first question that arises within the selection scheme is whether it contains inherent antagonisms. If not, that is if there are no serious negative genetic correlations between the elements of the selection goal, then it merely remains to optimize the selection scheme. In the strictly technical sense of maximizing the total economic value of genetic gain using given information this is a achieved by using a selection index. However, 
when the cost of the information used in the index is taken into account, a new dimension is added. Most of the work on cost effectiveness in cattle breeding seems to concern a particular case of this problem - reconciling costs and selection gains for dairy bulls used in AI.

If there are unfavourable genetic correlations, two courses of action may be possible. The first is to proceed with index selection. A case in point is the problem of improving milk yield and composition. Here one is forced to select in the face of difficult correlations, because the yield of a cow cannot be separated from the composition of her milk. The alternative course of action is to make two groups of the components of the total genotype and to pursue each group separately by selection in males or in females, in other words, to begin separate sire and dam line development. This idea has come to be fairly well accepted in pig breeding where it is now common to pursue heterotic effects in a hybrid female line, while improving the mainly additive performance and carcass traits by selection in a male line. It offers considerable possibilities in cattle populations also, and I would to like develop this idea in a later section. If the choice is for separate sire and dam lines, then the operational problems are first to choose and evaluate the potential lines, and secondly to optimize selection within lines.

This outline presents in broad terms the full spectrum of possibilities that our current knowledge of inheritance offers to livestock improvement. One can distinguish the strategic decisions that it contains - choice of breeding goal, choice of selection or crossing systems, choice of breeds, strains, or indeed populations. At a lower level are the tactical decisions concerned mainly with the optimization of operations within a given breeding structure. I believe that in cattle breeding, as in many other areas of human activity, we have tended to concentrate effort on the tactical choices, to the neglect of the strategic ones.

I would like first to review some work on cost effectiveness in the only area of cattle breeding where it has been studied to any extent - AI bull selection. I also wish to discuss the way in which the breeding programme interacts with the population structure and to indicate what appear to me to be some strategic options that have not been greatly appreciated.

\section{COS'T EFFECTIVENESS IN AI BREEDING SCHEMES}

\section{Genetic optimization for dairy traits}

The optimization of decision-making in dairy-cattle breeding, using Mendelian inheritance as a basis, can be said to have begun with the simple indexes described by LUSH (I945). The spread of artificial insemination in the I940's introduced a new phase of interest. The wide-spread use of a bull in AI made it both possible and imperative to estimate his genetic merit with increased accuracy. This immediately concentrated attention on the efficient use of progeny testing. Early work was concerned mainly with balancing the accuracy and intensity of progeny test selection of bulls so as to maximize the rate of genetic gain for milk yield (ROBERTSON, I954). With a limited pool of recorded cows in the population progeny group sizes, and 
therefore progeny test accuracy, can be increased only by reducing the number of bulls tested.

The main factors affecting this balance are the heritability, number of progeny records available $(\mathrm{N})$, number in each progeny test $(n)$, number of bulls tested $(\mathrm{N} / n)$, number required $(\mathrm{S})$, and proportion selected $(n \mathrm{~S} / \mathrm{N})$. RoBERTSON (I957) simplified the relationships between these factors by defining a testing ratio $K=N / S$. He was then able to describe algebraically population structures that maximized genetic gain largely as functions of SkJERvold (I964 b) developed these ideas further, and mapped the approaches to maximum gain for varying selection intensities, population sizes, heritabilities and inbreeding effect. RoBERTSON (I954), SKJERVOLD (I963), and SKJERVOLD and LANGHolz (I964 a) looked at the way in which selected bulls affect the population via their sons and daughters, and at the relative use of young and proven bulls. Their general conclusions were :

$I^{\circ}$ The main agency for population change is selection intensity among young bulls. To keep this high, a large proportion of services should be carried out by young bulls.

$2^{\circ}$ Very high selection intensity should be used for sires of bulls.

$3^{\circ}$ Approches to maximum rates of genetic gain are fairly gradual, so that considerable variation in breeding structure is possible, while still maintaining a high proportion of maximum gain.

These studies provided an adequate basis for rational decisions on the physical structure of AI breeding operations. Since they were published, two developments have reinforced their general conclusions. The first is that as selection schemes became more effective, particularly in the choice of sires and dams of bulls, the genetic merit of young bulls began to be as good as that of the previous generation of proven bulls, so that the emphasis on use of young bulls carries even greater weight. The second is the development of semen freezing and dilution techniques which have greatly extended the potential use of individual bulls, thereby making possible high selection intensity without a corresponding increase in the scale of the operation as a whole.

\section{Genetic and economic optimization for dairy traits}

The first systematic extension fo these ideas to include financial considerations was by PouTous and Vissac (I962). They set out to find the breeding structure that would maximize the total return on expenditure. They succeeded in writing a formula (25) for the cost-effectiveness of the programme as a whole. This formula contains sixteen parameters describing the physical, economic and genetic structure of the population. They chose to concentrate on progeny group size and level of bull selection, and found that the values of these variables which maximized cost-effectiveness depended in turn on the costs per progeny recorded and per bull maintained. In general, their results suggested milder intensities of bull selection than the previous studies. Their paper introduced several new elements into this area of work: consideration of the multi-generation effects of an insemination, of population structure and of interest rates and discounting procedures to allow for the spread in time of costs and returns. 
VAN VLECK (I964) constructed an algorithm which traced the cumulative gain in genetic merit in young and selected bulls from the start of a dairy progeny testing and selection programme. From this, it was possible to calculate the total gain from testing for any particular population. CunNINGHAM and CLEAVEs (I965) used this method to calculate the annual genetic gains over 20 years for a range of programmes in which number of insemination per bull, proven versus young bull usage, level of progeny recording and bull selection intensity were varied. CunNINGHAM (I966) added costs and calculated returns, demonstrating that the same programme is seldom optimum in both genetic and economic terms. Indeed in several situations, genetically optimum schemes cost more than the predicted return. For many combinations of structure however, the return on expenditure exceeded Io : I. BRASCAMP (I972) used discounting procedures to standardize the long-term effects of genetic improvement in milk yield through the four possible paths linking parents and offspring. His results showed that the path sire-son is less important from an economic than from a purely genetic point of view.

\section{Genetic and economic optimization for beef and dairy traits}

The extension of the basic model to include a measure of meat production in addition to milk immediately introduces several new dimensions to the problem of both genetic and economic optimization. SOLLER et al. (I966) adopted a selection index approach to the calculation of genetic gain in milk yeild and liveweight from various combinations of performance and progeny testing. To allow for the differential expression of bull merit for milk and beed traits, they introduced the idea of the composition of his average offspring, $i$. e. the proportion of his progeny in which the different products are obtained. They used quite detailed calculations to arrive at the net discounted value of gains in liveweight. They also studied variation in the relative economic values of milk and liveweight. Their general conclusions were that this ratio is relatively stable, and that under reasonably general conditions, the returns from dairy progeny testing are much greater than from beef testing. Beef performance testing is likely to be quite cost-effective, but beef progeny testing less so.

LINDHE (I968) studied the genetic and economic gains from beef performance testing followed by dairy progeny test selection of bulls. He introduced a new variable variable : the usage level for each bull selected, which becomes more a manageable factor with frozen semen. He looked first at the effect of five levels of prior selection on beef performance test on gains in milk. The effect was negligible, since the traits were assumed uncorrelated and the only interaction is in the need to use a larger number of bull dams to allow for culling fo their sons on performance test. He ordered the more than ro ooo alternative programmes possible by limiting consideration to those with a marginal return on capital exceeding ro p. Ioo. Among these, five alternatives covering the range of 20000 to 40000 doses of semen per bull were studied in detail. The higher levels of bull usage were more cost effective, but not greatly so. Average returns on capital for the programme as a whole were about I30 p. roo. Return on capital for the beef performance test alone was about 30 p. IOO.

HrNks (I970 $a, b)$ looked at costs and returns in bull testing and selection, 
first for dairy traits alone, and then with a beef performance test included, with the requirements of the British Milk Marketing Board's AI service particularly in view. He concluded that on the dairy programme, greater use of selected bulls, through frozen semen, would give substantial benefits, and that the costs involved in a policy of slaughtering bulls after IO-I5 ooo semen doses had been collected were too high for it to be recommended. His results also suggested that moderate selection intensities ( $\mathrm{up}$ to $\mathrm{I}$ in 7 ) were desirable. He found that performance, but not progeny testing for beef traits in dairy bulls could be justified in terms of return on capital. However, even performance testing gave a lower return than did marginal investment in the dairy progeny testing programme. It would require an increase in the relative values of meat and milk from $7:$ I to I2 : I to justify the diversion of investment to performance testing in these circumstances. In a further paper (HINks, I97I) he looked at the longer-term consequences of alternative dairy programmes, using as a measure of cost-effectiveness the discount rate at which a particular programme recovered its total costs a specified number of years the conclusion was that the main factors of importance were the bull selection intensity and the marginal profitability of milk production.

HILL (I97I) treated in detail the financial appraisal of alternative breeding programmes for meat production from a dairy population. In particular, he compared the returns from performance test selection in the dairy population and in a purebred beef population producing bulls for crossing on dairy cows. He gave particular attention to the use of discounted cash flow techniques and to the effect of varying discount rates. He concluded that investment in the production of beef breed bulls is better than investment in dairy bull performance testing, though the latter would also be profitable at interest rates up to $5 \mathrm{p}$. 100 .

MCCIINTOCK and CUNNINGHAM (I972) pointed out that since the unit of use of a selected bull is an insemination, and since the costs of the breeding programme are usually carried on the insemination charge, both costs and returns should be calculated per insemination. They developed a "discounted gene flow " method which adjusts the genetic effects of an insemination for the number of descendants it involves, their relationship to the animal being evaluated, and the time interval separating the insemination from its economic consequences. Using this method, they were able to define a milk plus beef breeding objective which maximizes the economic value of the genetic merit conferred by an insemination. Using an index selection of bulls for this aggregate genotype, they demonstrated that for a wide range of conditions the most cost-effective element in an integrated breeding scheme is the dairy progeny test, with beef performance testing on a lower level and beef progeny testing even less valuable.

The discounted gene flow method depends on the probability that an insemination will result in a dairy cow. This probability in turn depends on several parameters of population structure : reproductive rate, cow turnover rate and rate of crossing with beef breed bulls. CUNNINGNAM and MCCLINTOCK (I972) pursued the effects of variation in these parameters, since as they vary, so does the selection objective for which dairy or dual-purpose bulls should be chosen, and with it the whole breeding strategy that should be followed. It emerged that the rate of beef crossing in particular had a large effect. As beef crossing increases, the balance in the breeding objective moves towards milk, and so the relative cost-effectiveness 
of dairy and beef testing and selection also moves in favour of milk. With high beef crossing, the probability that a dairy insemination will lead to a dairy cow is greatly increased. As a result, the total genetic and economic consequences of the insemination are increased. This means that for a given expenditure on testing and selection the return can be increased by promoting beef crossing. They concludea therefore that the cost-effectiveness of dairy breeding programmes is greatly improved by the parallel use of beef breed bulls. This conclusion is dealt with again in the next section.

\section{Genetic and economic optimization for beef traits}

Few studies have been done on the cost-effectiveness of schemes for beef alone. MOCQUOT and FOULLEY (I973) compared selection on performance test, on progeny test, and on a two-stage use of both types of test for a beef breed used as a sire line for suckled veal production. They discounted costs and returns and made allowance for the reduction of variation due to prior selection in the two-stage case. They considered discount rates, duration of pay-off period, usage of selected bulls and variation in genetic parameters. They concluded that two-stage selection was best.

Other studies on economic optimization for beef cattle include that of LEIGH $e t$ al. (1972) who used linear programming methods to compare crossbreeding strategies. Their criterion was overall financial benefit of each programme, and this was influence by breed combinatign, size of cow, level of reproduction performance and farm size. The british M. L. C. SCIENTIFIC STUDY GROUP REPORT (I97I) includes cost-effectiveness considerations of beef breed substitution, selection for beef in dairy cattle and selection in beef breeds.

\section{POPULATION STRUCTURE AND GENETIC EFFICIENCY}

\section{Basic structures}

Consider first the simplest of structures in which we have a single population with a common breeding goal. Such might be the Dutch Friesian, Nerw Zealand Jersey, American Hereford or French Charolais populations. The goal may be beef, dairy or dual purpose. In each case the population structure is such that both the bulls and cows used for breeding are produced within the population. Because of the large number of new females needed each year to maintien population, size, these replacement heifers will be bred throughout the population.

In a population of traditional structure, the males used for breeding are produced by a relatively small subsection of the population. These bull-breeding herds usually, through not always, consist of pedigree cattle. In some countries this traditional structure is given a legal basis, with laws prohibiting the use of any but pedigree bulls. This type of structure undoubtelly was useful a century ago when the problem of improvement was seen as one of extending the use of improved strains through a largely nondescript unimproved population. It may even have merit to-day in some populations, since the elite nucleus of herds may be the only ones in which 
recording is carried on, and therefore the only ones in which objective selection can be practised. However, in a modern population this kind of structure does impose a restraint on the rate of genetic improvement, since it automatically excludes from the breeding programme males from most of the population. Since outstanding females can make a substantial mark on the population only through widely used sons, it also eliminates many of them.

This kind of structure was practically universal in European cattle populations until recent years. The spread of AI has levelled out genetic differences between herds. and in several countries the bulls used for breeding are now produced throughout the population. This may require that formal breed boundaries be disregarded, as in the Norwegian dairy population (SKJERVOLD, I972) or in a French beef population (RONDEAU, I972). A modern breeding structure of this kind does not support an elite of breeders, and so in general needs to be pioneered and promoted by an AI organization. Its most necessary feature is a means of identifying potential bull mothers in the population at large. Probably the most extensive such enterprise is the American cow indexing system (DICKINSON et al., 197I), through the methods are quite well developed elsewhere (g. e. BURNSIDE, I970). Considering the substantial gains possible from evevery simple bull dam selection (HENDERSON, I964), it seems that all populations served by $\mathrm{AI}$ will eventually tend to this type of structure.

\section{Beef crossing in dairy populations}

Whether the basic structure of a dairy cattle population is traditional or modern, it may be altered in another direction by the use of a certain amount of beef bulls, Beef crossing superimposed on such populations is illustrated in figure 2 . The beef bulls have no permanent effect on the population since all their progeny are slaughtered. The extent of beef crossing possible is determined mainly by the rate of cow turnover : the more lactations per cow, the fewer replacements needed annually and the more beef crossing can be practised. The limits to beef crossing, assuming that 35 animals of breeding age are produced per Ioo cows par year, are :

$\begin{array}{cc}\text { No. of lactations per cow } & \text { Percent of beef cros } \\ - & - \\ 3 & 2 \mathrm{I} .6 \\ 4 & 4 \mathrm{I} .2 \\ 5 & 52.9 \\ 6 & 60.8\end{array}$

In fact beef crossing is practised to any considerable extent only in Britain and Ireland, where the percentages of dairy cows mated to beaf bulls on I970 were 38 p. Ioo and 54 p. IOO, and in France where on Ig65 I6 p. Ioo of Friesian, 21 p. IOO of Normandy and 26 p. Ioo of Montbéliarde cows were lated to beef bulls.

The advantages of a certain amount of beef crossing are as follows :

- It allows for specialized selection for beef traits in the beef line and dairy traits in the female line, thus permitting faster genetic improvement in each sat of traits.

- It increases the possibility that a dairy insemination will result ultimately in a milking cow, and thus increases the net return to the farmer from that insemina- 


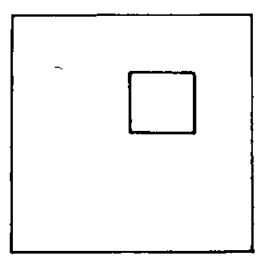

Traditional

Bulls bred in elite (usually pedigree) subsection. Cows bred throughout population

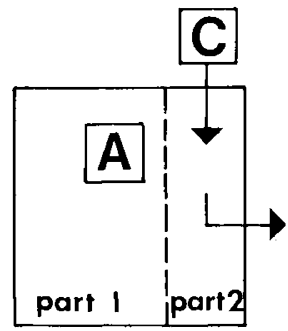

Traditional with beef crossing

all cows dual-purpose (line A)

all cows in part 2 mated to bulls of beef line $\mathrm{C}$ all their progeny slaughtered

Bulls of A line bred in elite subsection

Cows bred throughout part I of population

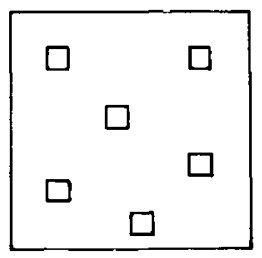

Modern

Bulls bred throughout population Cows bred throughout population

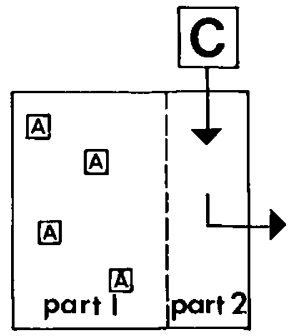

Modern with beef crossing

all cows dual-purpose (line A)

all cows in part 2 mated to bulls of beef line $($ : all their progeny slaughtered

Bulls of A line bred throughout part I of population

Cows bred throughout part I of population.

FIG. 2. - Basis breeding structures for dual-purpose cattle populations

Schéma d'accouplement de base pour des populations bovines à double fin

tion. This effect also increases (up to double) the return to the industry as a whole for money spent on dairy testing and selection.

- Since fewer dairy bulls are required, it allows the scale of the dairy testing to be reduced, while maintaining a given level of quality in the bulls selected.

- It forces the farmer to exercise more selection in the dams of this replacement heifers than might otherwise be the case. Each time he breeds a cow, he must decide if she is good enough for a dairy insemination.

- It provides a supply of beef $x$ dairy heifers which can be used as replacement cow for beef herds.

- If dairy heifers are mated to bulls of a specially selected beef breed calving problems can be minimized, and dairy inseminations can be concentrated on those cows which have completed at least one lactation.

- It allows the exploitation of whatever direct heterosis there is for beef traits. For growth alone, this can amount to $8.5 \mathrm{p}$. IoJ between beef breeds (GREGORY, I970) and at least 6 p. Ioo in beef $\times$ dairy crosses (M. L. C., I97I).

There are some disadvantages to beef crossing :

- It reduces the amount of culling that the farmer can practise among both incoming heifers and cows already in the herd. However, SyRSTAD (I972) has shown that while the maximum gain in current herd mean production from cow culling is $7 \mathrm{p}$. Ioo, 
the genetic effect on the herd is negligible. Few farmers can practise theoretically maximum rates of culling, and the selective mating of good cows to dairy bulls will tend to offset the effect of reduced culling levels. It appears therefore that the total adverse effect of beef crossing through reduced opportunities for cow culling will be small. A contrary view is taken by VAN VLECK (I972).

- If beef crossing near the limit is practised some herds may not have enough heifers for replacement in some years. This problem will be most acute in small herds, where variation in the sex ratio will be greatest. In these circumstances, a reduced level of beef crossing may be called for (LINDSTRöm, I970). The alternative is to develop a method for the exchange of heifer calves between farms.

The balance of advantage and disadvantage therefore seems to favour maximizing beef crossing. For a dairy population not already practising beef crossing, such a change in strategy will have widespread effects on the breeding programme. In the first place, some effort must be devoted to the testing and improvement of potential beef lines or breeds. Secondly, the balance of dairy and beef traits which are expresse 1 through each insemination by a dairy bull becomes such that bull testing and selection programme should overwhelmingly emphasize dairy traits. This means that large investments, and intensive culling, for beef traits in dairy bulls are not worthwhile. The rising demand for the more extreme dairy types of Holstein-Friesian in some European countries whose populations have in the past been firmly dualpurpose, indicates that milk producers are already seaking more specialized cattle in any case.

\section{Crossbreeding structures for single-goal populations}

The advantages of systematic breed crossing in populations of specialized beef cattle have been very adequately demonstrated. Literature summaries by MASON (I966) and CUNDIFFE (I970) and the report of a recent large trial by GREGORY (I970) all indicate that the cumulative advantages of crossbreeding can amount to 2025 p. IOo in terms of weight of calf weaned per cow per year. Despite this, little systematic stable breef crossing is done in the major beef producing countries. No doubt are there physical deterrents to crossbreeding under ranching conditions. However, it seems likely that the tend will be to greater use of crossbrazding in these countrie (CARTWRIGHT, I970). In European countries, beef production from pure beef breeds is found on a substantial scale only in France. While crossing among the French beef breeds is little practised, the large experiment at Bourges (LEFÈVRE and DARDE, I97I) may lead to developments in this direction.

The advantages of crossbreeding among dairy or dual purpose breeds is less well documental. However, the review by PEARSON and McDowel, (I968) of sevan large experiments indicated heterosis for survival rates, growth rates and milk production. Again, despite apparently worthwhile advantages, little systematic breed crossing is to be found in practice. Such crossing as does take place is largely in the form of " croisement d'absorption " in which males of one bread are used continuously on another breed so that a breed change takes place. Once the change is complete, the structure reverts to one of those described in figure 2.

Since most European cattle populations are dairy or dual purpose, wa can discuss possible crossbreeding structures for this kind of situation, through much 
of what follows could also relate to a specialized beef or indeed any single-goal population. The main questions which arise are :

- Whether a crossbreeding structure is preferable to a simple within-population selection structure.

- What kind of crossbreding structure is best.

On the first question, generalization is difficult because of the scarcity and variability of experimental results to-date, and because of the complexity of any measure of dairy merit. However, the review of PEARsON and MCDANIELL (I968) indicated heterotic gains averaging over $5 \mathrm{p}$. Ioo for milk yield. MCDower. and McDANIEL, (I969) showed a crossbred advantage for total economic dairy merit, and HoRN (I97I) found crossbred cows more productive than purebreds in a dual-purpose situation. These results must be qualified by the statement that in general the crosses involving Holstein-Friesian do not outproduce the pure Holstein-Friesian. However, the evidence does suggest that the cumulative heterotic advantages of crossbreeding are worth pursuing.

Assuming that this is the case, what structure best serves this end ? HILI (I97I) has thoroughly discussed the theoretical aspects of alternative crossbreeding structures. In cattle populations, certain practical factors limit the range of possibilities. To be useful, the structure must,

I. Be stable, i. e. maintain a constant genetic composition in the population.

2. Allow female replacements to be generated throughout the population.

3. Effectively exploit heterosis.

4. Not interfere with selection for additive traits.

Of the alternatives listed by HILL (I97I), only rotational crossbreeding fulfills these requirements. The options can be further narrowed to a comparison of two- and three-breed rotational crossing, since anything more complex is likely to be impractical in cattle.

Five of the experiments reviewed by PEARSON and McDowel, included 3-way crosses. In two of them the 3 -way crosses showed more, and in the other three, less, heterosis than the 2 -way crosses for milk production. So in general one might suppose equal heterosis effect. This, of course, refers only to the first generation. After about 3 generations of either two- or three-breed rotational crossing, the genetic composition of the population stabilizes with $86 \mathrm{p}$. Ioo of maximum heterozygosity in the case of the 3-breed, and $66 \mathrm{p}$. Ioo of maximum heterozigosity for the 2-breed structure. The question therefore is whether these two structure are likely to differ in heterotic effect. We have no experimental evidence on this in cattle. However, Skarman's (I965) experiments with pigs show that backcrosses (with only 50 p. roo of maximum heterozygosity) showed as much heterotic effect as the initial crosses. It is reasonable to theorize that the effects of heterosis lay not be a linear function of the degree of the heterozygosity and that the increase from $66 \mathrm{p}$. Ioo to $86 \mathrm{p}$. Ioo of maximum heterozygosity is unlikely to be worth pursing in cattle.

Two-breed crossing has some practical advantages over the use of 3 breeds. It is simpler to operate. Each herd contains just two types of cow : those to be mated to sires of line A and those to be mated to line B. Paralled selection in two lines is likely to be more affective than in three. The cost to the population of maintaining two 
sire lines is less than for three. In general, therefore, it appears that the choice of a crossbreeding structure for a dairy or dual-purpose cattle population should involve just two breeds.

This kind of structure is illustrated in figure 3. The mating plan can be called reciprocal back crossing (RBC). The main cow population consists entirely of crossbred cows. After the first few generations, every cow has a genetic constitution which is either $\mathrm{AAB}$ or $\mathrm{ABB}, i . e$. on average two-thirds of her loci contain genes from both $A$ and $B$ lines, while the remaining third contain genes of either the $A$ or the $B$ line. The mating rule is simple: if a cow's sire was from line A, she is mated to a bull of line $B$, and vice versa. A simple ear-notching convention could make this foolproof in practice.

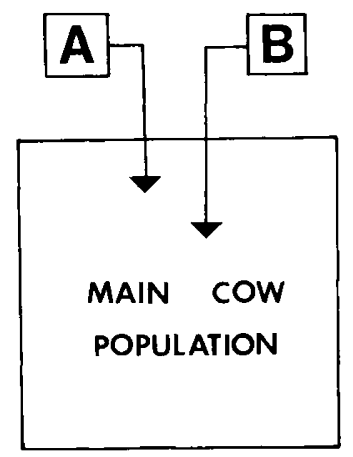

Two line RBC structure

Bulls bred in two dual-purpose sire lines with idertical goals

Cows bred throughout population by reciprocal back crossing to lines $A$ and $B$.

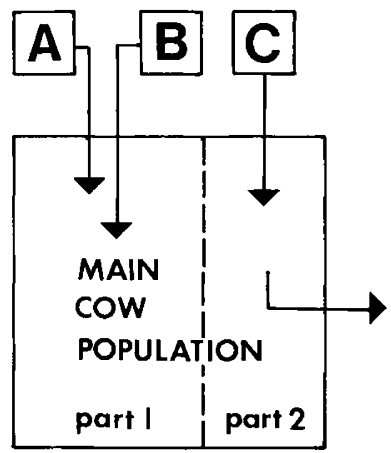

Two line RBC structure with beef crosstng

Bulls bred in two dual-pupose sire lines, A and B Cows bred in part $\mathrm{I}$ of population by reciprocal back crossing to lines $\mathrm{A}$ and $\mathrm{B}$

all cows in part 2 mated to bulls of beefline $\mathrm{C}$ all their progeny slaughtered

FIG. 3. - Crossbreeding structures for dual-purpose cattle populations

Schéma de croisement pour populations bovines à double fin

The approximate conditions which are necessary for such a crossbreeding structure to be worthwhile can be summarized follows :
I. $\mathrm{A}=\mathrm{B}$
(for additive merit)

2. $\mathrm{AAB}=\mathrm{ABB}=\mathrm{AB}$ (for heterotic merit)

3. $A A B, A B B \geqslant A, B$ (for additive merit)

4. $A A B, A B B \geqslant A, B$ (for heterotic merit)

The first condition says that the sire lines must be of roughly equal merit. If they are not, producers will continue crossing to the better line, as usually happens at present where one of the lines is Holstein or Friesian. In dairy cattle, therefore, a prerequisite for this kind of structure is the development of a strain genetically distinct form, but of equal additive merit to the Friesian. At least one attempt is currently being made (TEVERSON, I970) to produce such a line based on the red dairy breeds of Europe.

The second condition says that two-thirds of maximum heterozygosity should give approximately the same heterotic effect as full heterozygosity. The third and fourth conditions say that the $2 / 3$ crossbreeds should not be inferior to the purebreds for additive traits, and that the must be some heterosis worth pursuing in the first 
place. In our present cattle populations, these seem reasonable, if not yet fully supported by experimental evidence.

Such a structure is operable only in a population served by AI. In one sense, it reverts to the traditional structure, since bull production is now confined to two small purebred sub-populations. However, if their absolute size is reasonable (say Io ooo cows each) then bull dam selection efficiency might be kept at much the same level as in a population of modern structure. Sire selection would, of course, be based on progeny testing carried out as before in the main population. One of the side advantages of such a system is that inbreeding in the main population need no longer be of any concern. However, it is concentrated in the sire lines, so that, depending on their size, some degree of planed mating to minimize its effects might be necessary.

There is a further, if somewhat hypothetical advantage to such a structure. Bulls in lines A and B would be selected largely on additive merit based on their progeny test on crossbred daughters. If non-additive effects contributed to their progeny test, then the bulls selected in line A would be chosen in part for their genetic dissimilarity from line B. Thus the long-term effects of paralled selection in the two lines would be for genetic divergence, and hence the enhancement of heterosis between them.

Beef crossing can of course be superimposed on a two-breed crossbreding dairy population. This structure is also shown in figure 3 . The use of a beef line here could be even more advantageous than in a conventional dairy population, since it would reduce the number of bulls to be supplied by lines $\mathrm{A}$ and $\mathrm{B}$ and thus reduce the minimum size that these lines must achieve to keep inbreeding under control.

\section{Crossbreeding structures for two-goal populations}

In Ireland, $28 \mathrm{p}$. Ioo of the cow population consists of beef cows. In Scotland the figure is 57 p. IOO, in England I9 p. IOo, and in France 2I p. IOO. In other European countries, numbers of specialized beef cows are small, but growing. The two populations - of beef and dairy cows - may occupy geographically distinct areas, as in France, or they may also be intermingled, as is common in Britain and Ireland. In either case, their physical proximity to one another is close enough for an exchange of stock. This contrasts with the situation in most of the other major beef producing countries, whose dairy and beef populations may be very far removed form each other.

Whatever the structure in the dairy cow population, a certain amount of crossing with beef on dairy cows offers the opportunity for a very efficient link between the breeding structures of the two populations. All the evidence (e.g. CundiFFE, I960) suggests that beef cows should be crossbreds. British figures (M. L. C., I97I) show that the growth of beef calves out of beef $x$ dairy cows exceeds that of progeny of traditional beef type cows, with the advantage being greatest in good farming conditions. This suggests that the cows in the beef population could be bred in part 2 of the dairy population. This, in fact, in dairly commonly the practice in the British Isles. Using this source of replacement females for the beaf population has the following advantages :

- They should be available at a lower cost than females from within the beef population. 
- If the beef crossing line used on the dairy herd is of an early maturing type (Hereford or Ansug), the mature bodyweight of cows in the beef herd can be kept down. This can be quite important, since, for example, it has been calculated that in an Angus cow herd producing calves for sale at 6 months, $87 \mathrm{p}$. Ioo of the total feed imput to the herd is required for the maintenance and growth of the breeding animals (LONG and FITZHUGH, I969).

- It permits the exploitation of the full effects of crossbreeding in the female : complementarity of beef and dairy characteristics, together with the full effects of heterosis for maternal traits.

- The choice of terminal size line can be made to give further complementarity (large size in the male, moderate in the female) together with whatever further heterosis is achieved by the use of a third breed.

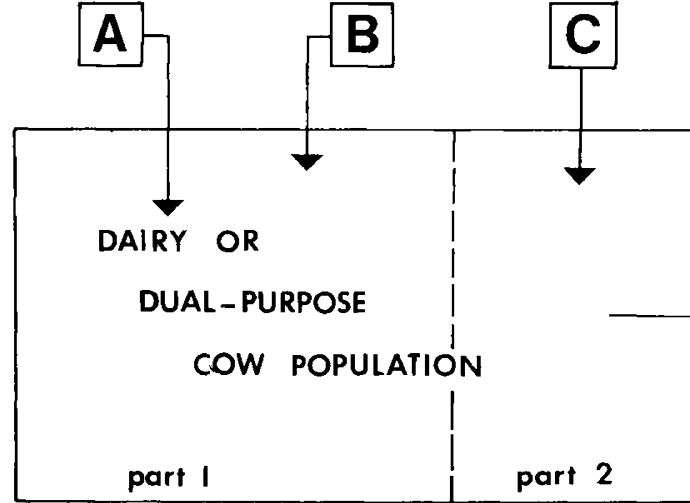

Dairy population

Bulls bred in two dairy or dual-purpose lines

Cows bred in part $\mathrm{I}$ of population by back crossing to lines $\mathrm{A}$ and $\mathrm{B}$

all cows in part 2 mated to bulls of beef line $C$. all their male progeny slaughtered

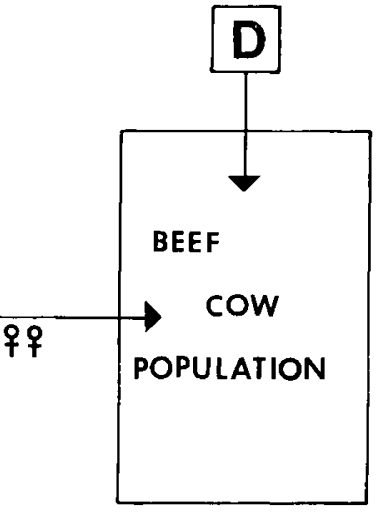

Beef population

Bulls bred in beef line D

Cows bred in part 2 of dairy population by crossing with bulls of beef line $\mathrm{C}$

all progeny slaughtered

FiG. 4. -- Breeding structure for linked dairy and becf populations

Schéma d'accouplement pour populations bovines à lait et à viande associées

In figure $4 \mathrm{I}$ have illustrated this structure linking a dairy and a beef population. The dairy population is shown as having basically a two-line reciprocal back crossing structure, though it could equally have any of the other structures already described. One consequence of this general kind of population structure is that it puts great importance on the choice of beef sire lines. In populations served by AI, and this is likely to be feasible in beef populations before long, the purebred nuclei from which these lines are drawn become extremely important sources of genetic improvement. A great deal of investment will therefore be justified in the formation and testing oi specialized beef sire lines. 


\section{RÉSUMÉ}

\section{RENTABILITÉ ET PROGRAMMES DE SÉLECTTION BOVINE}

Afin que les investissements soient productifs, il faut que les programmes d'utilisation des reproducteurs soient planifiés de façon appropriée du point de vue génétique aussi bien qu'économique. La planification consiste à choisir entre deux différents types d'action. Les décisions à prendre surgissent au niveau stratégique aussi bien qu'à celui tactique. La recherche a bien analysé les choix tactiques mais, en ce qui concerne les choix stratégiques, les plus importants, il reste encore beaucoup à faire.

Un schéma précis avec la succession des décisions à prendre pour un programme d'amélioration génétique est traité systématiquement. On examine aussi les travaux en cours concernant la planification génétique et économique de la sélection bovine. On parle également, de façon assez détaillée, de l'interaction entre de tels programmes d'amélioration génétique et la structure de la population.

\section{ZUSAMMENFASSUNG}

\section{KOSTEN-NUTZEN-VERHÄLTNISSE \\ UND POPULATIONSSTRUKTUR IN RINDERZUCHTPROGRAMMEN}

Günstige Kosten-Nutzen-Verhältnisse verlangen dass ein Zuchtprogramm sowolh genetisch wie ökonomisch gut geplant wird. Die Planung besteht im Entscheiden zwischen alternativen Vorgehen. Diese Entscheide stellen sich auf strategischer und taktischer Ebene. Es wird hervorgehoben, dass die Wissenschaft viele Arbeiten über die Wahl taktischer Verfahren geliefert hat, während dies den wichtigeren strategischen Verfahren nicht zutrifft.

Ein formelles Vorgehen wird beschrieben in welchem die Reihenfolge der notwendigen Entscheidungen für ein Zuchtprogramm systematische aufgeführt sind. Die aktuelle Literatur über genetisch-ökonomische Planung in Rinderzuchtprogrammen ist zusammengefasst. Die Beziehungen zwischen Zuchtprogrammen und Populationsstrukturen werden in mehreren Details dargestellt.

\section{REFERENCES}

Brascamp E. W., I972. Model simulation in an AI population with cattle. I. The economic value of genetic improvement. (Unpublished manuscript.)

BURNSIDE E. B., I970. Cow-indexing procedure and culling levels for potential dams of dairy bulls. $J$. Daity Sci., 53, I95-199.

- Cartwright T. C., I970. Selection criteria for beef cattle for the future. J. Anim.Sci. 30,706-7I I.

Cundiffe I. V., I970. Experimental results on crossbreeding cattle for beef production. J. Anim. Sci., 30, 694-705.

Cunningham E. P., Cleaves Janet, I965. Production of genetic gains in bull-proving programmes. E. A. A. P. Meetings, Noordwijk.

Cunningha.y I. P., I966. The genetic improvement of the Irish cattle population. J. Soc. Stat. Inquiry Soc. of Ireland, 26, 99-I 30.

Cunningham E. P., Mc Clintock A. E., 1972. Selection in dual purpose cattle populations : effect of beef crossing and cow replacement rates. Submitted to Ann. Génét. Sél. anim.

Dickinson Ii. N., McDaniel B. T., Norman H. D., ig7x. USDA-DHIA Cow performance Index List.

Dickerso: G. E., r97o. Efficiency in animal production. Molding the biological components. $J$. Anim. Sci. 30, 849-859.

Gregory Jeith E., 1970. Hybrid vigour in beef cattle. Massey University sheep-farming annual, 237249. 
Henderson C. R., I964. Selecting the young sire to sample in artificial insemination. J. Dairy Sci 47 , 439-44I.

Hill W. G., I97I. Investment appraisal for national breeding programmes. Anim. Prod., 13, 37-50. Hill W. G., I97I. Theoretical aspects of crossbreeding. Ann. Génét. Sél. anim., 3, 23-34.

Hinks C. J. M., I970 $a$. The selection of dairy bulls for artificial insemination. Anim. Prod., 12, 569-576.

HrNks C. J. M., I97r. The genetic and financial consequences of selection amongst dairy bulls in artificial insemination. Anim. Prod. 12, 209-218.

Hinks C. J. M., I970. Performance test procedures for meat production amongst dairy bulls used for AI Anim. Prod., 12, 577-584.

Horn A., Bozo S., Dunay A., r97r. The effect of size and type upon the efficiency of milk and beef production in cattle. Ann. Génét. Sél. anim., 3, 7I-83.

Lefevre C., Darde P., I97I. Le domaine expérimental de Bourges. I. N. R. A., Jouy-en-Josas.

Leigh A. O., Wilton J. W., Jenson E. A., I972. Optimum beef cattle crossbreeding stategies. $J$. Anim. Sci. (Abstr.) 35, 178 .

Lindhe B., I968. Model simulation of AI breeding within a dual-purpose breed of cattle. Acta Agric. Scand. 18, 33-4 I.

Lindström U., I970. Breed and crossbreeding for beef production in Finland. Zeitschr. Tierz. Züchtungs Biol., 87, 3I2-324.

Long C. R., Fitzhugh H. A., r969. Comparison of alternative beef breeding programmes. J. Anim. Sci., 28, rog.

Lush J. L., 1945. Animal Breeding Plans. Iowa State College Press.

Mason I. L., I966. Hybrid vigour in beef cattle. Anim. Br. Abs., 34, 453-47.3.

Meat and Livestock Commission, I97i a. Records Report No. 27. Groreth rates and weight for age of breeds and crosses. M. L. C. Bletchley, U. K.

Meat and Livestock Commission, i971 $b$. Beef improvement. Scientific Study Group Report. M. L. C. Bletchley, U. K.

McClintock A. E., Cunningham E. P., I972. Selection in dual-purpose cattle populations : defining the breeding objective. Anim. Prod. 5, I89-209.

Mocovot J.-C., Foulley J.-L., I973. Recherche des conditions de rentabilité d'un schéma de sélection d'une souche de bovins destinée au croisement de première génération pour la production de veaux de boucherie. Submitted to Ann. Génét. Sél. anim., 5, 189-209.

Pearson Lucia, McDowell. R. E., I968. Crossbreeding of dairy cattle in temperate zones : a review of recent studies. Anim. Br. Abs. 36, I-I5.

Pouto:s M., Vissac B, I 962 . Recherche théorique des conditions de rentabilité maximum de l'épreuve de descendance des taureaux d'insémination artificielle. Ann. Zootech. 11, 233-256.

Robertson A., I954. Artificial insemination and livestock improvement. Adv. in Genetics, 6, 45 I-472.

Robertson A., 1957. Optimum group size in progeny testing and family selection. Biometrics, 13, 442-450.

Rondeau M., 1972. Le développement de l'amélioration génétique dans le Sud-Ouest. Proc. Session d'Études d'A.C.T. I. M. I mars-26 avril, 1972 .

SkARMan S., I965. Crossbreeding experiments with swine. Lantbr. Hogsh. Annlr., 31, 3-92.

SKJERVold H., LANGholz H. J., I964 $a$. Factors affecting the optimum structure of AI breeding in dairy cattle. Zeitsch. Tierz. Ziuchtungsbiol., 80, 25-40.

SKJERVold H., LANGholz H. J., I964 $b$. Der optimate Einsatz der Nachkommenprufstationen in der zuchterischen Arbeit. Zeitschr. Tierz. Züchtungsbiol. 80, 197-207.

SKJERVOLD H., I963. The optimum size of progeny groups and optimum use of young bulls in AI breeding. Acta A gric. Scand. 23, I3I-I40.

SkJERvold H., LANGiolz R., I963. Optimum size of progeny groups. Optimum use of young bulls in AI breeding. Acta A gric. Scand. 13, 2.

Skjervold H., 1972. Cattle breeding in Norway. Ir. Grass. avd Anim. Prod. Assoc. J. 7, 92-I4

Soller M., Bar-Anan R., Pasternak K., Ig66. Selection of dairy cattle for growth and milk production. Anim. Prod. 8, ro-120.

SyRSTAD O., 1972. Effects of intensive culling in dairy herds. Acta A gric. Scand., 22, 25-28.

Teverson H. W. S., I970. A new role for the breeder, geneticist and breed society. Digest of the Brit. Cattle Breeders Club, 25, 3-12.

VAN VleCK L. D., I972. Breeding dairy heifers to beef tulls. Dairy Herd Management. 9, I8-19. VAN VLECK D., I964. Sampling the young sire in artificial insemination. J. Dairy Sci., 47, 44I-445. 